\title{
Genetic resources of vegetable crops and their safeguarding in Italy
}

\begin{abstract}
Italy belongs to the Mediterranean gene centre proposed by Vavilov and is rich in endemic rare plants and many vegetables, crops that belong to about 40 species. Horticultural landraces are a source of useful genes as well as a cultural heritage of extraordinary importance. They are characterized by a specific adaptation to the environmental and cultivation conditions of the particular area where they have been selected, so playing a crucial role in order to maintain and improve the efficiency and resilience of production systems. Vegetable crops, even if less threatened by genetic erosion than other crops, would benefit of in situ and ex situ conservation that are complementary both for taking in account agronomic, environmental and economic changes and for reintroducing lost germplasm into the original cultivation areas.
\end{abstract}

Volume 2 Issue 3 - 2018

\section{Laghetti G, Bisignano V, Urbano M}

National Research Council, Institute of Biosciences and Bio Resources (CNR-IBBR), Italy

Correspondence: Venturino Bisignano, National Research Council, Institute of Biosciences and Bio Resources (CNRIBBR),Via G.Amendola I65/A, 70126 Bari, Italy, Email venturino.bisignano@ibbr.cnr.it

Received: December 18, 2017 | Published: May 10, 2018

Keywords: agro biodiversity, genetic erosion, ex situ conservation, in situ conservation, landraces, safeguarding, vegetable crops

\section{Introduction}

Italy belongs to the Mediterranean gene centre proposed by Vavilov $^{1}$ and has a variety of different ecological, pedoclimatic, and orographic conditions. The Italian flora therefore is rich in endemics and rare plants ${ }^{2}$ and many crops have their original domestication centre there, showing a wide genetic and phenetic variability Vegetable crops in Italy, covering a total area of about 2,125,503 hectares, belong to about 40 species, forming a very heterogeneous group. With the exception of tomato (96,782 hectares), artichoke $(43,838$ hectares $)$ and potato $(35,601$ hectares $)$, fresh green bean, fresh peas, cauliflower, fennel, lettuce, chicory, melon, zucchini, onion, carrots and parsnips cover an area ranging from 11,408 to 21,160 hectares, while area of all other vegetables comprises only a few thousand hectares (Table 1). In Italy moreover the ancient and widespread habit to gather wild plants as a source of food or for other uses $^{3-5}$ has led, in some cases, to their domestication by local farmers. Recently this occurred for Diplotaxis tenuifolia (L.) DC, ${ }^{6}$ Silene vulgaris (Moench) Garcke ${ }^{7}$ Sinapis alba L ${ }^{8}$ Calamintha nepeta (L.) Savi and Micromeria thymifolia (Scop.) Fritsch. ${ }^{9}$ Scolymus hispanicus L. ${ }^{10}$ and very recently Salicornia patula. ${ }^{11}$ (Figure 1) The commercial distribution of vegetable seeds has almost completely replaced seeds harvested by farmer themselves enhancing the improved cultivars and hybrids; due to the rapid varietal evolution, they are usually available on the market for no more than three four years. Trade in seed is profitably and firmly in the hands of a small number of internationally operating seed multinationals. It is principally engaged in obtaining F1 hybrids derived from a narrow range of parental lines or "engineered" varieties that provide, as a result, the retention of a small number of well known traditional cultivars, gradually dismissing all others. The rapid spreading of few modern cultivars has resulted in a sudden loss of genetic variation not yet halted. The genetic erosion is also due to the increased level of urban spreading, the changes in socio-economic conditions and the destruction of natural environments by increased human activity. It appears overall more advanced in the lowlands than in the mountainous areas, and it has progressed further in the central and northern parts of Italy. Landraces, obsolete commercial cultivars, lines used in breeding work which are no longer used, represent a unique genetic variation wealth, the loss of which cannot be returned.

Horticultural landraces in particular are a source of useful genes as well as a cultural heritage of extraordinary importance. They are characterized by a specific adaptation to the environmental and the cultivation conditions of the particular area where they have been selected ${ }^{12-14}$ playing a crucial role in order to maintain and improve the efficiency and resilience of production systems, such as pest and disease regulation as well as future challenges. Moreover, they are closely associated with the traditional uses, knowledge, habits, dialects, and celebrations of the people who developed and continue to grow them; according to the FAO definition "Traditional knowledge may be regarded as an integral part of agro-biodiversity". ${ }^{15}$ Genetic erosion, very fast in cereals and other major field crops, is less pronounced in horticultural and minor "garden crops" that are often preserved in home gardens or at the boundaries of larger cultivations. ${ }^{16}$ The Italian territory, but especially inland areas of South Italy where small familyowned farms still exist, is particularly rich in vegetable germplasm represented by different landraces clearly distinguishable from other similar cultivars and closely linked to the local historical memory. The promotion of local products also contributes to the preservation of agro biodiversity. The production of certified products, in fact, could ensure similar or greater income as compared to switching to modern cultivars, and could encourage younger farmers to continue growing these old and precious vegetable crops. A large amount of crop germplasm would have already disappeared or would be lost if not properly valued and promoted through collective marks (Protected Denomination of Origin -PDO, Protected Geographic Indication -PGI, Traditional Specialty Guaranteed - TSG), which represent important regulatory instruments to protect consumers and to support small and medium farms.

Since 1976 the Italian Government through the Ministerial Decree 07.17.1976, established the "National Register of Horticultural Varieties" to face the problem of genetic erosion. The cultivars listed in the registry are preserved and kept in purity from/ by? seed 
companies or public institutions. An updated list in January 2017 is available on the web site. ${ }^{17}$ European Community implemented the problem concerning the preservation and enhancement of genetic resources for food and agriculture by the Council Regulation (EC) No 870/2004 relating to the conservation, characterization, collection and utilization of genetic resources in agriculture. The Italian Plan on Biodiversity of Agricultural Interest, approved on 14 February 2008 by the State-Regions Conference, has launched a new phase of multi-annual conciliation, in which the State and local authorities commit themselves, each according to their own competences, to the preservation and enhancement of Italian agro biodiversity. The Regions have inserted specific actions for the preservation and promotion of biodiversity in the Rural Development Programs 20072013 and 2014-2020.

Table I Vegetables in open field - year 2016 - area (hectares) and production (quintals) (ISTAT 2016)

\begin{tabular}{|c|c|c|}
\hline Vegetables & Area (ha) & Total Production (q) \\
\hline Tomato & 18,190 & $5,589,507$ \\
\hline Industrial tomato & 78,592 & $56,008,397$ \\
\hline Potato & 35,601 & $10,338,850$ \\
\hline $\begin{array}{l}\text { Fresh kidney beans and } \\
\text { french beans }\end{array}$ & 17,879 & I,494,257 \\
\hline Fresh peas & 16,202 & 989,116 \\
\hline Carrots and parsnips & II,408 & $5,333,383$ \\
\hline Onions & 12,710 & $4,590,631$ \\
\hline Globe artichoke & 43,838 & $3,896,251$ \\
\hline Cauliflower and broccoli & 16,259 & $4,025,346$ \\
\hline Fennel & 19,826 & $5,247,833$ \\
\hline Lettuce & 15,668 & $3,464,848$ \\
\hline Chicory & 13,910 & $2,632,134$ \\
\hline Melon & 21,160 & $5,503,190$ \\
\hline Zucchini & 14,704 & $3,674,314$ \\
\hline others & $\mathrm{I}, 789,556$ & $20,767,819$ \\
\hline
\end{tabular}

Figure I Cultivated plants of Scolymus hispanicus L. Along the fencing of a small farm located in the countryside of Lavello town (Basilicata region, Italy). $\mathrm{A}$ :Wild plants of $\mathrm{S}$. hispanicus growing in the same area; $\mathrm{B}$ : the most used part of this plant is the central leaf rib, a white fleshy part which is obtained by peeling off the leaf blade.

\section{Safeguarding constrains}

The numerous activities undertaken in a discontinuous way by the actors on the territory threaten to jeopardize the work already done with significant financial resources at regional, national and EU level. The lack of coordination has often led to overlaps of initiatives and a confusion of roles that would have been is appropriate to bring order to better leverage the work already conducted and efficiently address future activities. Therefore, it is necessary that all the phases of recovery, characterization, conservation and valorization be taken only and exclusively on the proposal and in agreement to local public or private actors, located and operating in the territory in question. It is important, for example, to harmonize the methodological approaches used in the collection, classification and characterization of the material creating a constructive interaction between those who, having monitored the territory, want to retain ownership of genetic material collected and bodies responsible for the proper storage of the material collected. Moreover, the evaluation of the stored material and studies on the interaction genotype $\times$ environment on the most interesting local varieties are completely in adequate and further studies are required. Likewise, knowledge of the most effective ex situ conservation methods is incomplete and further developments of these activities, highly expensive, need adequate funding. Ex situ and in situ conservation are complementary and should be used together to achieve an integrated strategy. In fact, while ex situ conservation is a static method functional to preserve germplasm over time of fundamental importance for reintroducing lost germplasm into the original cultivation areas, in situ strategy is more dynamic, taking in account agronomic, environmental and economic changes. Last, but not least important priority is the definition of the risk threshold beyond which the cultivars are considered at risk of extinction and that therefore require protection. These thresholds should be recognized and shared by all scientific and non-scientific subjects who work in this field.

\section{Conclusion}

In the future, there will be an increasing need to develop sustainable agricultural systems, for both food and energy and to preserve cultivated and related wild species against genetic erosion. The gene banks can definitely play a decisive role, complementary to the in situ conservation with a more careful planning. In this perspective, a greater economic effort is desirable aimed at the development of research, the maintenance of gene banks and the continuous monitoring of the state of the collections. A political and normative commitment in this sense is crucial, supporting the ex situ conservation. Vegetables crops, even if less threatened by genetic erosion than other crops (e.g. cereals), would benefit of the above mentioned safeguarding strategies.

\section{Acknowledgements}

None.

\section{Conflict of interest}

Authors declare that there is no conflict of interest.

\section{References}

1. Vavilov NI. Geografičeskie zakonomernosti v raspredelenii genov kulturnych rastenii. Trudy prikl bot gen i sel. 1927;17:3.

2. Pignatti S. Flora dItalia. Bologna, Edagricole: 1982;2:732.

3. Bianco VV. Piante spontanee della flora italiana utilizzate come ortaggi. In: 
Pàtron, edtitor. Orticoltura, Patron, Italy; 1990:969-983.

4. Ditonno NM, Lamusta S. Sapori e aromi da piante e frutti spontanei della Puglia peninsulare. Amici della A. De Leo. Brindisi, 1997.

5. Guarrera PM. Usi e tradizioni della flora italiana Medicina popolare ed etnobotanica. Roma: Aracne; 2006.

6. Hanelt P. Cruciferae. Verzeichnis landwirtschaftlicher und gärtnerischer Kulturpflanzen (ohne Zierpflanzen). In: Rudolf Mansfelds Schultze Motel J, Akademie Verlag, editors. Berlin; 1986:272-332.

7. Laghetti G. Utilization or Silene vulgaris (Moench) Garcke in ltaly. Economic Botany. 1994;48(3):337-339.

8. Maly R, Hammer K, Lehmann Chr O. Sammlung pflanzlicher genetischer Ressourcen in Süditalien - ein Reisebericht aus dem Jahre 1950 mit Bemerkungen zum Schicksal der Landsorten "in situ” und in der Genbank. Die Kulturpflanze. 1987;35(2):109-134.

9. Hammer K, Laghetti G, K Pistrick. Calamintha nepeta (L.) Savi and Micromeria thymifolia (Scop.) Fritsch cultivated in Italy. Genetic Resources and Crop Evolution. 2005;52(2):215-219.

10. Laghetti G. Microevolution of Scolymus hispanicus L. (Compositae) in south Italy: from gathering of wild plants to some attempts of cultivation. JARTS Supplement. 2009;92:119-126.
11. Urbano M, Tomaselli V, Bisignano V, et al. Salicornia patula DuvalJouve: from gathering of wild plants to some attempts of cultivation in Apulia region (southern Italy). Genetic Resources and Crop Evolution. 2017;64(6):1465-1472.

12. Harlan JR. Our vanishing genetic resources. Science. 1975;188(4188):618-621.

13. Zeven AC. Landraces: a review of definitions and classifications Euphytica. 1998;104(2):127-139.

14. Saxena S, Singh AK. Revisit to definitions and need for inventorization or registration of landrace, folk, farmers' and traditional varieties. Curr Sci. 2006;91(11):1451-1454.

15. FAO. Report on the state of the World's plant genetic resources for food and agriculture. 2009.

16. Hammer K, Perrino P. Plant Genetic Resources in South Italy and Sicily studies towards in situ and on-farm conservation. Plant Genet Res Newsl. 1995;103:19-23.

17. Aggiornamenti Registro nazionale varietà ortive. registro italiano varietà vegetali. 2017. 